Health scientists strike over cuts at Argentinian labs

[LONDON] Staff at Argentina's largest public health laboratory are taking indefinite strike action in protest at large-scale staff and budget cuts to the country's seven national institutes of health.

Employees at the National Institute for Microbiology are protesting against a 37 per cent cut in the supplies budget, and 100 job losses from a total workforce of 900 . Striking staff are occupying the institute's buildings and have vowed to continue their action unless the decision is reversed.

The microbiology institute is the largest of the seven national health institutes which include centres for medical genetics, nutrition and epidemiology. The institute has 370 staff and is responsible for monitoring and controlling infectious diseases, such as the current outbreak of hantavirus in the south of Argentina, which is causing 20 new cases each week, and an outbreak of cholera in the north. Researchers working in disease control are not on strike.

The cuts are part of wide-ranging reforms designed to prune Argentina's bureaucratic public sector. A spokesman says that redundancies have been made largely among non-essential staff. None of the axed scientists, he says, works in disease prevention and control.

But Jeronimo Cello, a researcher at the National Institute for Microbiology, says research scientists make up half of those being made redundant, including many with skills and knowledge not easily found in Argentina. "This is a ridiculous waste of rare scientific talent."

Negotiations between the two sides have so far proved fruitless. The strikers are pinning their hopes on a petition filed in the courts alleging that the government acted illegally by firing its employees. A decision is expected later this week.

EhsanMasood

\title{
Study discloses financial interests behind papers
}

[WASHINGTON] The debate about whether scientists should declare their financial interest in research published in leading journals has been rekindled by a study of almost 800 original articles published in 1992 by academics from research institutions in Massachusetts.

The reviews, which covered papers appearing in 14 journals of cell and molecular biology and medicine, found that onethird of lead authors had a direct financial interest in the published research.

The journals covered in the study, which was published last month in Science and Engineering Ethics, include Nature, Nature Genetics, Science, The New England Journal of Medicine (NEJM), The Lancet and the Proceedings of the National Academy of Sciences (PNAS).

Overall, 15.3 per cent of 1,105 lead authors (defined as the first and last authors named) had a financial interest in at least one of the articles. Lead authors of 34 per cent of the 789 papers had a financial interest in the research they were describing.

'Financial interest' was defined as: the author being listed as an inventor in a patent or patent application closely related to the published work (this occurred in 22 per cent of the articles studied); serving on a scientific advisory board of a company developing products related to the author's expertise (20 per cent); or serving as an officer or major shareholder of a company with commercial interests related to the research ( 7 per cent).

Consultancies, personal financial holdings and honoraria were excluded, on the grounds that such links could not be adequately documented.

"If we're serious about making financial interest a part of the ethics of science, then we have to address the magnitude of the commercial ties that scientists have with their work," says Sheldon Krimsky, professor of urban and environmental policy at Tufts University in Medford, Massachusetts, and the lead author of the new study.

Krimsky suggests extending a 1995 policy that now applies to scientists seeking federal grant money in the US Public Health Service, which includes the National Institutes of Health. This requires grant applicants to disclose "significant" financial interests of more than $\$ 10,000$ that "reasonably appear to be affected" by the proposed research. The National Science Foundation has a similar policy.

Krimsky argues that such disclosure should also be required of all federally funded scientists seeking to publish papers in scientific journals. At present, some journals require authors to disclose any commercial associations that might pose a conflict of interest. Others require disclosure to the journal's editors when authors submit articles. Neither policy is universally accepted.

Some scientists protest that what they describe as an implicit suggestion of wrongdoing by authors who have financial interests in their subjects risks creating an atmosphere of 'scientific McCarthyism'. "It's crucial in science to judge a work by its merit and not by the author or authors' alleged biases," says Kenneth Rothman, a professor of public health at Boston University and editor of Epidemiology.

Rothman attacked the mandatory disclosure policies of some journals in a 1993 essay in the Journal of the American Medical Association (JAMA) $(269,2782-2784 ; 1993)$. The growing aversion of editors to publishing work by authors with financial interests in their subjects "diminishes scientific interchange, in the long run reduces objectivity, and harms scientific method", he says.

But others say that the study has thrown useful light on an important trend. George Lundberg, the editor of JAMA, says that financial conflicts of interest among scientific authors are "widespread" but that readers are largely unaware of them "because so many editors are not following what we consider to be good editorial practices of requiring and publishing financial disclosures routinely". (JAMA, which was not part of the study, requires financial disclosure by its authors.)

Among the 14 journals studied, four require financial disclosure by authors: Science, NEJM, The Lancet and PNAS. But in 1992 - the year of the study - only NEJM required disclosure. Science introduced its disclosure policy in July 1992, The Lancet in 1994 and PNAS in 1996. Meredith Wadman 